\title{
Centre-based care is a significant predictor of lower body mass index in early childhood: Longitudinal evidence from Chile
}

\author{
Kasim Allel ${ }^{1,2,3}$, Marigen \\ Narea $^{4,5}$, Eduardo A \\ Undurraga ${ }^{2,6}$ \\ ${ }^{1}$ Institute for Global Health, Uni- \\ versity College London, UK \\ ${ }^{2}$ Millennium Nucleus for the Study \\ of the Life Course and Vulnerabili- \\ ty (MLIV), Chile \\ ${ }^{3}$ Society and Health Research Cen- \\ tre, Facultad de Humanidades, \\ Universidad Mayor, Santiago, \\ Chile \\ ${ }^{4}$ Centre for Advanced Studies on \\ Educational Justice (CJE), Pontifi- \\ cia Universidad Católica de Chile, \\ Macul, Santiago, Chile \\ ${ }^{5}$ School of Psychology, Pontificia \\ Universidad Católica de Chile, \\ Macul, Santiago, Chile \\ ${ }^{6}$ Escuela de Gobierno, Pontificia \\ Universidad Católica de Chile, \\ Macul, Santiago, Chile
}

Background The prevalence of childhood overweight has increased by approximately $50 \%$ in the past three decades, becoming a major public health concern worldwide. In Chile, an upper middle-income country, about 38\% of children between two and four years of age are overweight, almost double the average in Latin America and the Caribbean. Various environmental and individual factors, and their interactions, affect childhood weight. Emerging evidence suggests childcare may also matter. Because the public provision of centre-based care is growing, childcare may be a useful policy tool to help prevent childhood overweight.

Methods Using a nationally representative longitudinal survey of $\sim 15000$ children in Chile (2010 and 2012), we estimated whether the type of child care (centre-based or maternal) a child attended at age 24 to 36 months was a significant predictor of the child's sex-and-age-specific body-mass-index (BMI) at age 36-48 months. We restricted our sample to children in full-time maternal care at baseline $(12-24$ months of age; $n=1273)$, but tested the robustness of results with the full sample. We compared children in centre-based care and in maternal care using difference-in-difference estimators and propensity score matching, and adjusted our estimates using child, family, and neighborhood characteristics.

Results Children attending centre-based care had 0.27 SD lower BMI than children in maternal care at follow-up $(P<0.05)$. We found suggestive evidence this association may be modulated by the child's socioeconomic status and by how frequently the child watched television: we found smaller BMI changes for children at the bottom $80 \%$ of socioeconomic status $(P<0.05)$ and also for children who frequently watched television $(P<0.10)$. Our results were robust to various model specifications.

Conclusions Our findings suggest centre-based care programs, with adequate regulation and enforcement, may be a useful support to help curb the early childhood overweight epidemic, in addition to known effects in labor supply and child development.

\section{Correspondence to:}

Marigen Narea

School of Psychology

Pontificia Universidad Católica de

Chile

Av. Vicuña Mackenna 4860

Office 19 Macul

Santiago 7820436

Chile

mnarea@uc.cl

Childhood overweight has become a major public health concern in most countries across the globe. The prevalence of childhood overweight, defined as age and sex standardized body mass index (BMI)>two standard deviations (SD) from the World Health Organization (WHO) growth standard median, has increased by approximately $50 \%$ in the past thirty years. This increase has not only affected high-income countries, but many middle and low-income countries as well [1-3]. The some- 


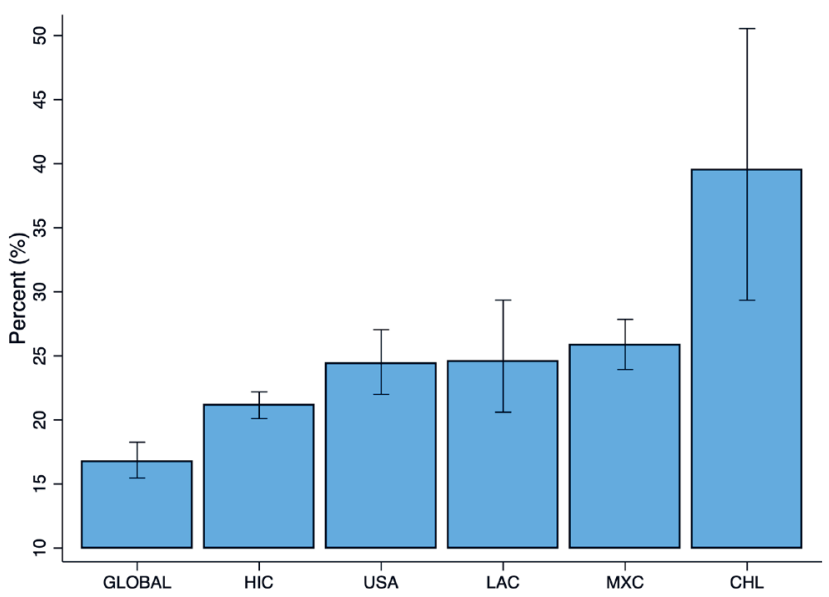

Figure 1. Estimated percentage of overweight or obese children between two and four years of age in selected countries and regions for 2015. Data of prevalence of overweight and obesity in children from GBD Obesity Collaborators [13]. Overweight was defined as BMI-for-age $>2$ standard deviations from WHO growth standard median. GLB - global rates, HIC - high-income countries, LAC - Latin American and the Caribbean, MXC - Mexico, CHL - Chile. times called "obesity pandemic" [4,5] is among the most relevant public health debates in the Americas; childhood overweight is particularly high in the United States [6-8] but also in some islands of the Caribbean, and in Mexico, Costa Rica, Uruguay, and Chile [1,9-11]. The prevalence of overweight and obesity in children under 6 years of age in Chile was 34\% in 2013 [12]. In 2015, the prevalence of overweight and obesity in children between two and four years of age in Chile (38\%) almost doubled the average prevalence of overweight and obesity in Latin America and the Caribbean [13] (Figure 1)

Several environmental and individual factors, and their interactions, affect childhood weight $[4,14]$. Environmental factors associated with increases in childhood obesity include changes in food systems such as the increasing availability and accessibility of energy-dense foods [4,15,16], food marketing $[4,13]$, economic development and wealth [16-19], reduced energy expenditure from urbanization and technological change [20]. Obesity is also affected by individual factors, including genetic makeup [21-23], behaviour (eg, physical activity, television viewing, sleep) [24-27], cultural preferences (eg, nutrition, body norms) [28,29], and

possibly the microbiome [30]. Complex interactions between environmental and individual factors explain observed variations in obesity rates between population subgroups [4].

A vast amount of research has shown the potential health risks and adverse consequences of childhood overweight and obesity, such as type II diabetes mellitus, respiratory afflictions, and psychosocial stress, and its potentially devastating consequences later in life, including a higher risk of developing cardiovascular diseases, diabetes, musculoskeletal disorders, and some cancers [3,13,31-38]. Early prevention of childhood overweight and obesity has increasingly taken a central stage in the global policy debate [39-45], focusing largely on behavioral changes and lifestyle and environment modifications [15,46-49]. Because young children depend on parental o caregivers' decisions, changes in the provision of child services, including centre-based care (CBC), may also be important. The term centre-based care $(\mathrm{CBC})$ is often used to refer to a nursery for young children, typically under the age of five [50]. CBC is a relevant policy tool that, in addition to known effects on labor supply and child development [51-53], could potentially help curb the obesity pandemic by, for example, providing adequate nutrition, encouraging physical activity, and promoting parental education [54-58].

Growing evidence suggests childhood overweight could be affected by CBC services, although there is no closure on the magnitude or direction of this association. At least three studies, in Canada, the USA, and The Netherlands [59-61] found that attending CBC in early childhood (1-4 years of age) was associated with a higher prevalence of overweight or obesity. These studies suggested weight gain in CBC may be explained by poor quality or limited regulation of nutritional and physical activity programs. In contrast, at least five studies in the USA have found CBC attendance was negatively associated with child overweight and obesity [62-66]. Broadly, those authors suggest $C B C$ may protect against overweight by promoting a healthier diet and providing health care [62]. Yet other studies have found no association between CBC and childhood overweight [67-74]. Attending CBC could be associated with lower risk of child overweight or obesity through several pathways, including planned nutritional programs and learning environments, healthy eating, regular opportunities for physical activity, regular bedtime and rise time, and reduced screen time (eg, computers, mobile phones, television) [62,63,75,76].

Much of what we know about the relation between $\mathrm{CBC}$ and overweight comes from high-income western countries and has focused on type-of-care effects (eg, maternal care, centre-based care). In addition, previous studies have shown heterogeneous sampling designs; most previous studies lack behavioral data (eg, screen time, sleeping), operational data about each specific type of care (eg, main source of funding,), and hours spent in $\mathrm{CBC}$. Most previous estimates of the relation between $\mathrm{CBC}$ and overweight are associative, and could thus be biased by omitted confounders, such as access to child care, demographic heterogeneity (eg, race, ethnicity), and/or CBC characteristics [77]. 
We estimated whether the type of child care (centre-based or maternal) at age 24 to 36 months was a significant predictor of a child's (i) sex-and-age-specific body-mass-index (BMI) and (ii) the probability of being overweight (BMI>two standard deviations, SD), at age 36-48 months. Using a nationally representative longitudinal survey of 15000 children in Chile (2010 and 2012), we compared children in centre-based care $(\mathrm{CBC})$ and in maternal care using difference-in-difference estimators and propensity score matching (PSM) to reduce omitted variable biases.

We think Chile is an apt location for this study for at least three reasons. First, most evidence on the association between $\mathrm{CBC}$ and childhood overweight comes from industrialized countries. Second, Chile has the highest rates of childhood overweight and obesity in South America [12,78]. Third, the Chilean government provides subsidized $C B C$ for children from the first three quintiles of household income distribution since $2006[79,80]$, with government-regulated dietary intake and infrastructure. Child enrolment in publicly funded $\mathrm{CBC}$ has thus increased substantially during the past decade, with $67 \%$ of children $<5$ years of age enrolled in $\mathrm{CBC}$ in 2017 [81]. Public CBC programs include three meals for children enrolled full time (breakfast, lunch, and an afternoon meal), providing about $60 \%$ of daily calories required (about 800 calories) [82]. Despite recent efforts to improve social programs for child development, Chile is among several middle income countries where childhood overweight is a major public health concern; our results provide external validity to previous findings with comparable CBC coverage and childhood overweight to the US and Canada [83,84]. To our knowledge, this is the first study to explore CBC as a plausible policy intervention that could help curb the childhood obesity epidemic in Latin America.

\section{METHODS}

\section{Data sample}

We used data from the Chilean Early-Childhood Longitudinal Survey (ELPI, 2010 and 2012) [85], a nationally representative data set of about 15000 children between six months and five years of age at the time of the 2010 survey (ie, born between January 1, 2006 and August 31, 2009). ELPI [85] includes household-level sociodemographic, economic, and educational data, and several child-development measures, including anthropometrics. Using a baseline (2010) sample of children in maternal care between 12 and 24 months of age, we compared indicators of sex- and age-specific BMI for children in CBC and in full-time maternal care at follow up (2012; n=1273; Figure 2).

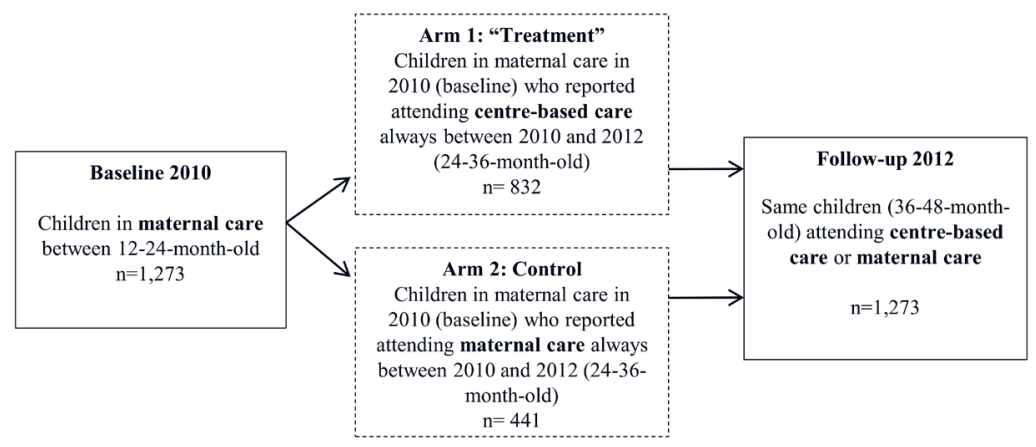

Figure 2. Definition of the study sample.

\section{Health outcomes}

Data on children's weight and height were collected in each survey round by trained research staff using a portable stadiometer and scale, during a household visit. We computed BMI $\left(\mathrm{kg} / \mathrm{m}^{2}\right)$ and defined overweight as having >2 SD from the age-sex standardized growth median BMI of a cohort of well-nourished international population $[86,87]$.

\section{Variables}

Attendance to $\mathrm{CBC}$ was asked retrospectively for children of 0-24 and 24-36 months of age ("Did your child attend $\mathrm{CBC}$ between the age of 24 to 36 months?"; $1=$ child attended $\mathrm{CBC}, 0=$ otherwise). Parents were also asked about the child's main caregiver at ages 0 through 24 months. We restricted the sample to children in maternal care at baseline (2010). Household and family background are associated with childhood overweight $[88,89]$, particularly parental overweight [90]. We used mother characteristics as 
a proxy for parental characteristics since all households in our sample had data on mother's characteristics. Table 1 shows variable definitions.

\section{Statistical analysis}

\section{Main models}

We used three main model specifications to understand the association between type of childcare and short-term changes in child's BMI. We reduced bias from potentially confounding variables that predict

Table 1. Definition of variables used in the main analysis*

\section{Variabie naMe Definition}

Dependent variables (outcomes)

BMI and Delta-BM

BMI is defined as child weight divided by body height squared $\mathrm{kg} / \mathrm{m}^{2}$ ). Delta-BMI was calculated as child's BMI in 2012 - child's BMI in 2010

\begin{tabular}{ll}
\hline Overweight & $1=$ BMI-for-age $>2$ SDs from WHO growth standard median; $0=$ otherwise \\
\hline Child characteristics & Age of the child at the time of the survey (in months) \\
\hline Female & Child's gender. $1=$ girl, $0=$ boy \\
\hline Television & $\begin{array}{l}\text { Number of hours (range) that the child spends watching television on a typical day. } 0=\text { child } \\
\text { does not watch television, } 1=\text { less than } 1 \mathrm{~h} \text { per day, } 2=1-2 \mathrm{~h} \text { per day, } 3=2-3 \mathrm{~h} \text { per day, } 4=3-4 \\
\mathrm{~h} \text { per day, } 5=4-5 \mathrm{~h} \text { per day, } 6=\text { more than } 5 \mathrm{~h} \text { per day }\end{array}$ \\
\hline Premature & $1=$ the child was born prematurely $(<36$ gestational weeks); $0=$ otherwise \\
\hline Video-games & Number of hours the child spends using a cell-phone in a typical day $(0-6 \mathrm{~h})$ \\
\hline Sleep & Total number of hours that the child sleeps during a typical day \\
\hline Caesarean & $1=$ child born by caesarean section; $0=$ vaginal delivery \\
\hline Illness & $\begin{array}{l}\text { Number of illnesses that the child has experienced since birth. Ranges from } 0 \text { to } 12, \text { assigns } \\
\text { one point for each of the following illnesses: respiratory, stomach, kidney, growth, visual, lis- } \\
\text { tening, skin, learning, mental health, traumatology, dental, neurological, and motor problems }\end{array}$ \\
\hline Older sibling & $1=$ child has an older sibling; $0=$ otherwise \\
\hline BMI at birth & $1=$ child had BMI $<25^{\text {th }}$ percentile at birth; $0=$ otherwise
\end{tabular}

\section{Maternal characteristics}

\begin{tabular}{|c|c|}
\hline Age $\dagger$ & Mother's age at the time of survey (years) \\
\hline Ethnicity & $1=$ mother speaks at least one indigenous language, $0=$ otherwise \\
\hline BMI & Weight divided by body height squared $\left(\mathrm{kg} / \mathrm{m}^{2}\right)$ \\
\hline Overweight status & $1=\mathrm{BMI}>2 \mathrm{SD}$ from growth standard median; $\mathrm{O}=$ otherwise \\
\hline Married & $1=$ mother was married at the time of the survey; $0=$ otherwise \\
\hline Worked before birth & $1=$ mother was working before child's birth; $0=$ otherwise \\
\hline Smoke & $1=$ mother smoked during pregnancy; $0=$ otherwise \\
\hline Depression & $1=$ mother has been diagnosed with depression (self-reported); $0=$ otherwise \\
\hline Chronic disease & $\begin{array}{l}\text { Number of chronic diseases that have affected the child's mother. Ranges from 0-22, with } 1 \text { for } \\
\text { each of the following diseases: lung, stomach, kidney, growth, listening, visual, skin, learning, } \\
\text { traumatology, cancer, diabetes, hypertension, heart, obesity, depression, anxiety, bipolarity, } \\
\text { schizophrenia, autism, hyperactivity, alcoholism, and drug problems }\end{array}$ \\
\hline Cigarettes & Number of monthly cigarettes smoked during the child's first 6 months of age \\
\hline \multicolumn{2}{|l|}{ Household characteristics } \\
\hline SES & $\begin{array}{l}\text { Index of SES based on five variables: parental occupation from low to high skills (range of } 9 \\
\text { values), parental years of schooling, household income per person [91]. Index ranges from } \\
-2.5 \text { to } 2.5 \text {; higher scores indicate higher SES }\end{array}$ \\
\hline Region & Categorical variable indicating region of residence in Chile (0-15) \\
\hline HOME score & $\begin{array}{l}\text { Abbreviated version of the Home Observation for Measurement of the Environment (HOME). } \\
\text { The score measures quality of social, emotional, and cognitive support for children at home } \\
\text { (ranges from 0-22, with higher numbers indicating better environment) [92]. }\end{array}$ \\
\hline \multicolumn{2}{|l|}{ Other covariates $\ddagger$} \\
\hline SES status $(40 \%, 60 \%, 80 \%)$ & $\begin{array}{l}\text { Categorical variable indicating whether the children belonged to the } 40 \%, 60 \% \text {, or } 80 \% \text { most } \\
\text { vulnerable children by SES ( } 1=\text { child was among the X\% more vulnerable; } 0=\text { otherwise) }\end{array}$ \\
\hline Part-time & $1=$ child attended a CBC during 4 or less hours in a typical day; $0=$ otherwise \\
\hline Full-time & $1=$ child attended a CBC full time ( $8 \mathrm{~h}$ per day); $\mathrm{O}=$ otherwise \\
\hline Private & $1=$ child attended private $C B C$ program; $0=$ otherwise \\
\hline Public & $1=$ child attended public $\mathrm{CBC}$ program; $0=$ otherwise \\
\hline
\end{tabular}

BMI - body mass index, CBC - centre-based care, SES - socioeconomic status, SD - standard deviation.

*There was $18 \%$ attrition between baseline and follow-up.

$\dagger$ Age squared was also used in the regressions for the main analysis.

¥Interacted with CBC attendance to present joint associations in separate models. 
selection into CBC ("treatment"), using propensity score matching (PSM) to generate two comparable groups. PSM uses a logistic regression to predict participation in CBC. Based on observable characteristics at baseline (covariates shown in Table 1), children in the sample receive a propensity score and are then matched to create statistically comparable groups of treated (CBC) and non-treated (maternal care) children [93] (see supplementary material for further details).

In Model 1 we used a weighted difference-in-differences Ordinary Least Squares [47] regression with individual time-unvarying covariates and robust standard errors (Equation 1):

$$
\left(B M I_{i, t}-B M I_{i, t-1}\right)=\beta_{0}+\beta_{1}\left(C B C_{i, t}\right)+\Sigma \beta_{k} X_{k, i, t-1}+\varepsilon_{i, t}
$$

Where the subscripts ( $i$ ) stand for child, $(k)$ for the covariates included, and $(t)$ for time, with $t=$ follow-up survey and $t-1=$ baseline. BMI denotes age- and sex-specific body-mass-index and $\mathrm{CBC}$ indicates whether the child attended $C B C(C B C=1)$ or maternal care $(C B C=0)$. Because we used PSM, $\beta_{1}$ captures the average treatment effect of attending $\mathrm{CBC}$ compared to maternal care, as individuals were "treated" in 2012 (average treatment effect on the treated). $X_{k}$ is a vector of explanatory covariates at baseline (Table 1). $\varepsilon$ is an error term.

Model 2 was based in Equation 1, but allowed individual's characteristics to vary in time $\left(X_{k, i, 2012}-X_{k, i, 2010}\right)$, using time-varying covariates with PSM (Equation 2):

$$
\left(B M I_{i, 2012}-B M I_{i, 2010}\right)=\beta_{0}+\beta_{1}\left(C B C_{i, 2012}\right)+\Sigma \beta_{k}\left(X_{k, i, 2012}-X_{k, i, 2010}\right)+\left(\varepsilon_{i, 2012}\right)
$$

In Model 3, we used short-term General Linear Squares with fixed-effects and PSM added as weights (Equation 3). We used BMI as dependent variable and kept the time-varying covariates from Model 2. Model 3 allowed us to compare the robustness of estimates in Model 1 and Model 2, and to estimate individual's fixed effects between waves given by $\gamma_{i}$ (time-invariant differences between individuals). $\beta_{1}$ in this model shows the linear change in BMI from attending $C B C$ :

$$
B M I_{i, j}=\beta_{0}+\beta_{1}\left(C B C_{i, 2012}\right)+\Sigma \beta_{k} X_{i, j}+\varepsilon_{i, j}+\gamma_{i}
$$

\section{Additional analysis}

We provided two additional analyses. First, we tested the robustness of the association between attending $\mathrm{CBC}$ and $\mathrm{BMI}$, by examining a simpler model without covariates, and also by comparing $\mathrm{CBC}$ with any other type of care in the survey. Second, we explored the mechanisms through which the type of $\mathrm{CBC}$ could affect BMI. In Model 4 we expanded Model 1 and Model 2 by adding plausible moderators of the association between $\mathrm{CBC}$ and child weight (SES group, frequency of watching television, part-time or full-time attendance to $\mathrm{CBC}$, and whether $\mathrm{CBC}$ was public or private), and an interaction term between these moderators and $\mathrm{CBC}$.

All analyses were done using STATA 15.1 (StataCorp, College Station, TX, USA) and/or RStudio Version 1.1.383. Inc. Boston MA, EEUU.

\section{RESULTS}

\section{Descriptive statistics}

Table 2 shows descriptive statistics of the sample at baseline (2010). About 21\% of children between 12 and 24 months of age were overweight or obese at baseline (2010) (Figure S1 in the Online Supplementary Document). Approximately one third of the sample (35\%) attended CBC programs between 24 and 36 months of age. Compared to children in maternal care, children enrolled in CBC watched less television, were more frequently ill, and slept fewer hours $(P<0.01)$.

\section{Propensity score matching}

Based on observable characteristics at baseline, PSM showed the predicted probability of attending CBC was comparable for children who remained in maternal care (untreated) and children who attended CBC (treated) (Tables S1 and S2, and Figure S2 in the Online Supplementary Document). The number of hours the child spent watching television and sleeping were negatively associated with the likelihood that the child attended $\mathrm{CBC}\left(\beta_{\mathrm{TV}}=0.15, P<0.01 ; \beta_{\text {sleep }}=-0.32, P<0.01\right)$. In contrast, $\mathrm{SES}$ and the number of illnesses the child had experienced since birth were positively associated with the likelihood of attending $\mathrm{CBC}\left(\beta_{\mathrm{SES}}=0.22, P<0.05 ; \beta_{\text {Illnesses }}=0.18, P<0.05\right)$. 
Table 2. Descriptive statistics of the sample at baseline (2010), children 1-2 years of age in maternal care*

\begin{tabular}{|c|c|c|c|c|}
\hline & \multicolumn{2}{|c|}{ TYPE OF CARE AT 2-4 YeARS } & \multirow[t]{2}{*}{ T-IEST } & \multirow[t]{2}{*}{ TOTAL } \\
\hline & Maternal care & Centre-based care & & \\
\hline Child's characteristics & Mean \pm SD & Mean \pm SD & P-value & Mean \pm SD \\
\hline BMI & $17.66 \pm 1.96$ & $17.87 \pm .92$ & 0.09 & $17.73 \pm 1.95$ \\
\hline Overweight or obesity (\%) & $18.19 \pm 38.6$ & $20.18 \pm 40.18$ & 0.39 & $18.88 \pm 39.15$ \\
\hline Age & $19.43 \pm 2.94$ & $18.84 \pm 2.66$ & 0.04 & $19.18 \pm 2.85$ \\
\hline Female (\%) & $50 \pm 50.3$ & $47.23 \pm 49.98$ & 0.43 & $49.04 \pm 50.01$ \\
\hline Television $\dagger$ & $2.58 \pm 1.56$ & $2.32 \pm 1.38$ & $<0.001$ & $2.48 \pm 1.51$ \\
\hline Premature child (\%) & $7.51 \pm 26.37$ & $8.2 \pm 27.47$ & 0.59 & $7.75 \pm 26.75$ \\
\hline Video-games $\dagger$ & $0.67 \pm 1.01$ & $0.67 \pm 0.96$ & 0.97 & $0.67 \pm 0.99$ \\
\hline Sleep $\dagger$ & $10.92 \pm 1.25$ & $10.48 \pm 1.09$ & $<0.001$ & $10.77 \pm 1.21$ \\
\hline Caesarean (\%) & $41.48 \pm 49.3$ & $41.56 \pm 49.34$ & 0.79 & $41.51 \pm 49.29$ \\
\hline Illness & $0.75 \pm 0.82$ & $0.92 \pm 0.90$ & $<0.001$ & $0.81 \pm 0.85$ \\
\hline Older sibling (\%) & $63.5 \pm 48.17$ & $52.77 \pm 49.98$ & $<0.001$ & $59.79 \pm 49.05$ \\
\hline BMI at birth & $13.72 \pm 1.5$ & $13.68 \pm 1.51$ & 0.64 & $13.71 \pm 1.50$ \\
\hline \multicolumn{5}{|l|}{ Mother's characteristics: } \\
\hline Age & $28.84 \pm 7.05$ & $27.21 \pm 7.02$ & $<0.001$ & $28.25 \pm 7.09$ \\
\hline Ethnicity (\%) & $8.49 \pm 27.89$ & $6.92 \pm 25.41$ & 0.35 & $7.95 \pm 27.06$ \\
\hline Overweight status (\%) & $64.62 \pm 47.84$ & $57.56 \pm 49.48$ & 0.05 & $62.17 \pm 48.51$ \\
\hline Married (\%) & $78.87 \pm 40.84$ & $72.51 \pm 44.7$ & 0.01 & $76.67 \pm 42.31$ \\
\hline Worked before birth (\%) & $19.15 \pm 39.37$ & $21.95 \pm 41.44$ & 0.23 & $20.12 \pm 40.11$ \\
\hline Smokes (\%) & $8.94 \pm 28.55$ & $11.56 \pm 32$ & 0.11 & $9.85 \pm 29.81$ \\
\hline Depression (\%) & $10.45 \pm 30.61$ & $14.63 \pm 35.38$ & 0.04 & $11.9 \pm 32.4$ \\
\hline Chronic disease & $0.83 \pm 1.32$ & $1.01 \pm 1.55$ & 0.03 & $0.89 \pm 1.41$ \\
\hline Cigarettes & $6.12 \pm 3886$ & $6.65 \pm 29.45$ & 0.78 & $6.35 \pm 35.87$ \\
\hline \multicolumn{5}{|l|}{ Household characteristics: } \\
\hline SES & $-0.04 \pm 0.66$ & $0.08 \pm 0.70$ & 0.01 & $0.00 \pm 0.68$ \\
\hline Region & $8.92 \pm 3.77$ & $8.75 \pm 4$ & 0.45 & $8.88 \pm 3.85$ \\
\hline HOME score & $14.92 \pm 3.19$ & $15.16 \pm 3.14$ & 0.20 & $14.99 \pm 3.17$ \\
\hline Number of participants & 832 & 441 & & 1273 \\
\hline
\end{tabular}

\section{Main results}

Table 3 shows the main results from the regression analysis: attending $C B C$ was associated with lower BMI across models. Table 3, Model 1, suggests that compared with children who were always in maternal care, children who attended CBC between 2010 and 2012 saw an average decrease of .27 SD of their $\mathrm{BMI}\left(\beta_{\mathrm{CBC}}=-0.27, P=0.03\right)$. Results in Model 2, using a full difference-in-differences model accounting for the variability in child's characteristics in time, are consistent with Model 1 . Being enrolled in CBC in 2012 was associated with a 0.26 SD reduction in BMI compared to maternal care $\left(\beta_{C B C}=-0.26, P=0.05\right)$. Last, Model 3, shows comparable results when using fixed effects to isolate the individual's unvarying and heterogeneous characteristics $\left(\beta_{\mathrm{CBC}}=-0.25, P=0.07\right)$.

To be sure our results did not hinge on model specification, we further examined the association between $\mathrm{CBC}$ and BMI (i) excluding all covariates, with and without propensity score matching (Table S3 in the Online Supplementary Document), and (ii) comparing CBC with any other type of care (ie, maternal care, grandparent care, care by acquaintances/relatives) using a larger sample (Table S4 in the Online Supplementary Document). Overall, these results show that the negative association between $\mathrm{CBC}$ and BMI is robust.

\section{Additional results}

To understand the mechanisms that may explain our main findings, we examined the interaction between $\mathrm{CBC}$ and (i) SES, (ii) television, (iii) full or part-time attendance to $C B C$, and (iv) main source of funding (private or public). Table 4 shows several interesting findings. The association between CBC and BMI remained negative, large in magnitude, and statistically significant in most models. Table 4, Panel A.1, 
Table 3. Association between the type of care and changes in BMI-for-age for children between two and four years of age

\begin{tabular}{|c|c|c|c|c|c|c|}
\hline & \multicolumn{2}{|c|}{ MODEL 1} & \multicolumn{2}{|c|}{ MODEL 2} & \multicolumn{2}{|c|}{ MODEL 3} \\
\hline & \multicolumn{2}{|c|}{ OLS DID with PSM } & \multicolumn{2}{|c|}{ OLS DID with PSM } & \multicolumn{2}{|c|}{ FE with PSM } \\
\hline Main independent outcomes & $\boldsymbol{\beta}(\mathrm{SE})$ & $P$-value* & $\boldsymbol{\beta}(\mathrm{SE})$ & $P$-value* & $\boldsymbol{\beta}(\mathrm{SE})$ & $P$-value* \\
\hline \multicolumn{7}{|l|}{ Child characteristics: } \\
\hline Centre-based care & $-0.27(0.13)$ & 0.03 & $-0.26(0.14)$ & 0.05 & $-0.25(0.14)$ & 0.07 \\
\hline Age & $0.26(0.24)$ & 0.28 & $-0.10(0.05)$ & 0.04 & $-0.12(0.03)$ & $<0.001$ \\
\hline Age squared & $0.00(0.01)$ & 0.46 & $0.00(0.00)$ & $<0.001$ & $0.00(0.00)$ & $<0.001$ \\
\hline Female & $0.200(0.14)$ & 0.13 & - & - & - & - \\
\hline Television & $0.01(0.05)$ & 0.94 & - & - & - & - \\
\hline Premature & $0.12(0.23)$ & 0.60 & - & - & - & - \\
\hline Video-games & $-0.13(0.07)$ & 0.03 & - & - & - & - \\
\hline Sleep & $-0.04(0.06)$ & 0.54 & - & - & - & - \\
\hline Caesarean & $0.03(0.14)$ & 0.78 & - & - & - & - \\
\hline Illness $\dagger$ & $0.05(0.08)$ & 0.52 & $0.00(0.06)$ & & $-0.01(0.06)$ & 0.92 \\
\hline Older Sibling & $-0.02(0.17)$ & 0.86 & - & - & - & - \\
\hline BMI at birth & $0.19(0.14)$ & 0.17 & - & - & - & - \\
\hline \multicolumn{7}{|l|}{ Mother characteristics: } \\
\hline Age & $0.13(0.07)$ & 0.06 & $-0.03(0.17)$ & 0.86 & $-0.01(0.17)$ & 0.94 \\
\hline Age squared & $-0.00(0.00)$ & 0.03 & $0.00(0.00)$ & 0.35 & $0.00(0.00)$ & 0.21 \\
\hline Ethnicity & $-0.03(0.33)$ & 0.96 & - & - & - & - \\
\hline BMI & $0.05(0.01)$ & $<0.001$ & $0.03(0.02)$ & 0.10 & $0.04(0.02)$ & 0.05 \\
\hline Married $\ddagger$ & $-0.08(0.16)$ & 0.63 & $0.00(0.14)$ & 0.99 & $-0.01(0.15)$ & 0.95 \\
\hline Worked before birth & $0.00(0.17)$ & 0.97 & - & - & - & - \\
\hline Smokes & $0.21(0.23)$ & 0.35 & - & - & - & - \\
\hline Depression & $0.02(0.20)$ & 0.89 & - & - & - & - \\
\hline Chronic disease $\dagger$ & $0.00(0.06)$ & 0.94 & $0.00(0.14)$ & 0.99 & $0.02(0.14)$ & 0.87 \\
\hline Cigarettes & $0.00(0.00)$ & 0.28 & - & - & - & - \\
\hline \multicolumn{7}{|l|}{ Household characteristics: } \\
\hline SES & $0.20(0.10)$ & 0.03 & $0.03(0.15)$ & 0.83 & $-0.01(0.15)$ & 0.96 \\
\hline Region & $0.01(0.02)$ & 0.58 & - & - & - & - \\
\hline Constant & $-6.51(2.45)$ & 0.01 & $-0.47(0.93)$ & 0.61 & $21.19(3.65)$ & $<0.001$ \\
\hline Number of individuals & \multicolumn{2}{|c|}{1273} & \multicolumn{2}{|c|}{1268} & \multicolumn{2}{|c|}{1268} \\
\hline \multicolumn{7}{|c|}{$\begin{array}{l}\text { BMI - body mass index, DID - difference in differences, OLS - ordinary least squares, FE -fixed effects model, PSM - propensity } \\
\text { score matching, SES - socioeconomic status. } \\
\text { *Two tailed tests were employed for } P \text { values estimation. } \\
\text { †Illness and chronic disease were replaced by dichotomous variables expressing a change between panel waves in the Full DID and } \\
\text { FE models, ie, the appearance of a chronic condition or child illness. } \\
¥ \text { For the full DID and FE models married reflects a change in marital status ie becoming unmarried between panel waves }\end{array}$} \\
\hline
\end{tabular}

Table 4. Plausible mechanisms to explain the association between attending centre-based care and BMI-for-age in children between two and four years of age (Model 4)

\begin{tabular}{|c|c|c|c|c|}
\hline & \multicolumn{2}{|c|}{ DID w/PSM (N = 1273) } & \multicolumn{2}{|c|}{ FüL DID พітн PSM (N = 1268) } \\
\hline Main outcome in the regression & $\boldsymbol{\beta}(\mathrm{SE})$ & P-value* & $\boldsymbol{\beta}(\mathrm{SE})$ & P-value* \\
\hline \multicolumn{5}{|l|}{ A. Lifestyle moderators } \\
\hline \multicolumn{5}{|l|}{ A.1: SES $(80 \%$ more vulnerable $) \dagger$} \\
\hline Centre based care & $-0.71(0.26)$ & $<0.001$ & $-0.74(0.26)$ & $<0.001$ \\
\hline SES $<80 \% \times$ Centre based care & $0.55(0.31)$ & 0.06 & $0.60(0.31)$ & 0.05 \\
\hline SES $<80 \%$ & $-0.45(0.21)$ & 0.03 & $-0.46(0.21)$ & 0.03 \\
\hline Constant & $-6.23(2.47)$ & $<0.001$ & $-0.18(0.93)$ & 0.84 \\
\hline \multicolumn{5}{|l|}{ A.2: Television: } \\
\hline Centre based care & $-0.64(0.25)$ & 0.01 & $-0.68(0.26)$ & $<0.001$ \\
\hline Television $\times$ Centre-based care & $0.15(0.09)$ & 0.09 & $0.17(0.09)$ & 0.07 \\
\hline Television & $-0.06(0.05)$ & 0.22 & $-0.09(0.05)$ & 0.09 \\
\hline Constant & $-6.24(2.43)$ & 0.01 & $-0.19(0.94)$ & 0.84 \\
\hline \multicolumn{5}{|l|}{ B. Centre-based care moderators } \\
\hline \multicolumn{5}{|l|}{ B.1: Full and part-time assistance } \\
\hline Full-time & $-0.46(0.17)$ & $<0.001$ & $0.46(0.16)$ & $<0.001$ \\
\hline Part-time & $-0.06(0.17)$ & 0.06 & $-0.05(0.18)$ & 0.06 \\
\hline Constant & $-6.10(2.46)$ & 0.01 & $-0.49(0.93)$ & 0.60 \\
\hline \multicolumn{5}{|l|}{ B.2: Public and private funding } \\
\hline Private & $-0.36(0.25)$ & 0.15 & $-0.25(0.23)$ & 0.10 \\
\hline Public & $-0.24(0.15)$ & 0.08 & $-0.26(0.15)$ & 0.08 \\
\hline Constant & $-6.58(2.43)$ & $<0.001$ & $-0.45(0.94)$ & 0.60 \\
\hline
\end{tabular}

DID - difference in differences, PSM - propensity score matching, SES - socio-economic status.

*Two tailed tests were employed for $P$-values estimatio. We used the same covariates as shown in Table 3.

$\uparrow$ Results including children at in the lower second and third quintiles of socioeconomic status (lower $40 \%$ and $60 \%$ respectively) are shown in Table S5 in the Online Supplementary Document. 
suggests the magnitude of the association between attending $\mathrm{CBC}$ and BMI was smaller for children at the bottom $80 \%$ of SES $\left(\beta_{\mathrm{CBC}}+\beta_{80 \% \mathrm{SES} \times \mathrm{CBC}}=-0.71+0.55=-0.16\right.$, F-joint test $\left.=3.84 ; P=0.02\right)$, than for children at the top $20 \%$ of SES $\left(\beta_{\mathrm{CBC}}=-0.71 ; P=0.003\right)$. We examined the interaction between $\mathrm{CBC}$ and children at the second and third quintiles of SES, but found no significant results (Table S5 in the Online Supplementary Document). We also found suggestive evidence that watching television diminished the magnitude of the negative association between $\mathrm{CBC}$ and $\mathrm{BMI}\left(\beta_{\mathrm{TV} \times \mathrm{CBC}}=0.15 ; P=0.09\right)$. The results in Table 4 , Panel A.2, suggest the decrease in BMI from attending CBC may even disappear for children watching more than 4 hours of television per day $\left(\beta_{\mathrm{CBC}}+\beta_{\mathrm{TV} \times \mathrm{CBC}}=4 \times[0.15]-0.64=-0.04\right.$, F-joint test $\left.=3.65 ; P=0.03\right)$. Attending CBC full-time was significantly associated with lower BMI $\left(\beta_{\mathrm{FT}}=-0.46, P<0.001\right)$, but the association was not significant for children attending $C B C$ only part-time. Last, we found only suggestive evidence public funding could also mediate the association between CBC and BMI $\left(\beta_{\text {public }}=-0.24, P=0.08\right)$.

Changes in BMI do not necessarily imply a change in weight status category (ie, underweight, normal weight, overweight, or obese). Weight status categories matter as a health metric, for example, to un-

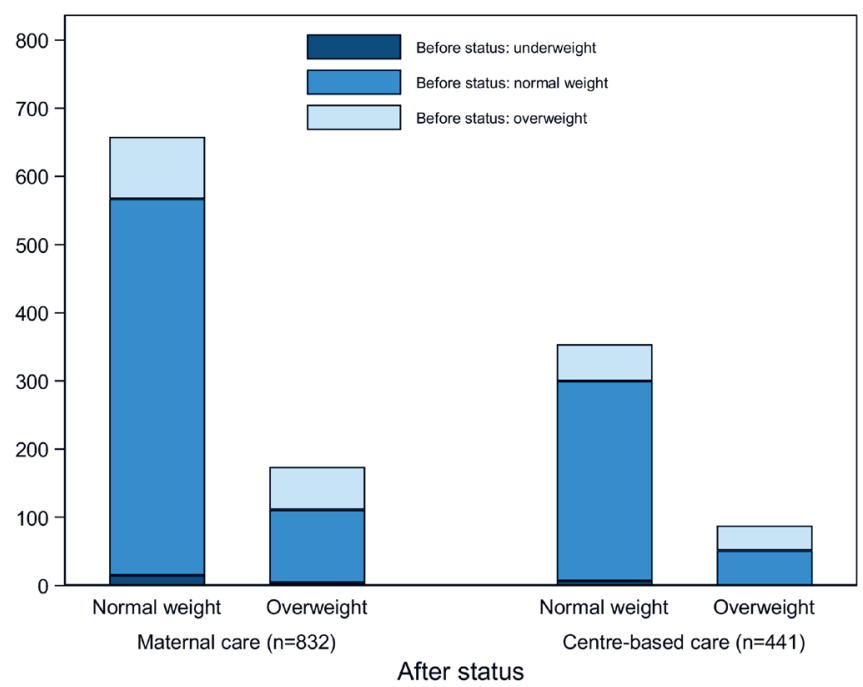

Figure 3. Changes in weight category between 2010 (before status) and 2012 (after status) for children at the age of 36-48 months. Underweight category is not reported in 2012, as they represented less than $1 \%$ of the sample. Overweight rate was $22 \%$ in 2010 for children in maternal care, while $26 \%$ for children in centre-based care, however, they changed to 26\% and 24\% in 2012. derstand trends or measure health progress. We used a logistic regression to examine the association between attending CBC and the probability of a child being classified as overweight in 2012 (Table S6 in the Online Supplementary Document). We found no statistically significant association between CBC and overweight status. But being a boy $\left(\beta_{\text {Female }}=-0.33\right.$; odds ratio $(\mathrm{OR})=0.72$; $P<0.05)$, caesarean-born $\left(\beta_{\text {cesarean }}=0.34 ; \mathrm{OR}=1.41\right.$; $P<0.05)$, and having a mother with overweight $\left(\beta_{\text {Mother- }}\right.$ weight $=0.37 ; \mathrm{OR}=1.45 ; P<0.05)$ were associated with a greater probability of child overweight (Table S6 in the Online Supplementary Document).

We last examined the relation between type of care and changes in BMI, focusing on transitions in weight status category. Figure 3 shows the change in weight status category between 2010 (children were 12-24 months old) and 2012 (children were 36-48 months old), by type of childcare (CBC and maternal). Overall, Figure 3 shows there were more overweight children in maternal care than in CBC. Between 2010 and 2012, the proportion of overweight children increased from $22 \%$ to $26 \%$ ( 4\%) for children in maternal care and decreased from $26 \%$ to 24\% ( 2\%) for children in CBC.

\section{DISCUSSION}

Based on a difference-in-difference analysis with PSM, our main results suggest that (i) attending CBC, compared to maternal care, was associated with lower BMI in early childhood, and (ii) this association was larger for children attending full-time care, and at the top $20 \%$ of SES, and smaller for children who watched television. (iii) Being a boy, caesarean born, and having a mother with overweight, increased the probability of child overweight. Potential policy implications include preventing childhood overweight by favoring access to CBC programs during early childhood.

First, our results are consistent with studies from high-income countries showing CBC programs, compared to maternal care, may help prevent children's gains in BMI and thus reduce their risk of becoming overweight [62-66]. One probable explanation for these findings relates to existence of a regulated, structured feeding pattern for children attending CBC (ie, three meals per day with balanced nutrition) [82], compared to more free feeding practices under maternal care $[94,95]$. This hypothesis is consistent with the fact that attending CBC full-time was significantly associated with lower BMI $(P<0.001)$, but the association was not significant for children attending CBC only part-time. The finding that CBC programs, compared to maternal care, may help prevent children's gains in BMI could have important policy implications, in the context of increasing childhood obesity. While our study has a stronger claim to causality than previous studies, and we have partially addressed common biases in previous literature, the "true" effects of CBC still need to be confirmed using a prospective study design that allows controlling for unobservable variables. 
Second, we found suggestive evidence that the association between BMI and CBC may be modulated by the child's SES status and by how frequently the child watched television. Specifically, we found larger BMI changes for children at the top $20 \%$ of SES compared to children at the bottom $20 \%$ of SES. This could be explained by differences in the intensity of exercise - that in turn depends on the centres' infrastructure - and differences in the quality of food in centres attended by children of different SES [96], particularly for children in the top quintile of income distribution.

We also found smaller changes in BMI for children who more frequently watched television. Some studies have found attending CBC may reduce the total time a child watches television [62,63,75]. Full-time enrolment at $\mathrm{CBC}$ was also a significant mediator of the association between $\mathrm{CBC}$ and $\mathrm{BMI}$; a plausible pathway is through active-learning and improved nutrition at CBC $[62,63,75]$. We found only suggestive evidence that public funding could mediate the association between $\mathrm{CBC}$ and BMI, which would be consistent with the mediating effect of SES. Publicly funded CBC programs, such as Head Start in the USA, have also found lower risk of child overweight $[62,63,75]$.

Third, we examined factors that could explain changes in children's weight status. Being born by caesarean section, being a boy, and having a mother classified as overweight, were all risk factors for childhood overweight, consistent with previous findings in the literature [39-44,97].

It is important to highlight these results were obtained using data from Chile, where the government provides subsidized $\mathrm{CBC}$ for children at the bottom $60 \%$ of the income distribution. Dietary intake (three meals) and childcare infrastructure are regulated and adequate quality standards enforced $[79,80]$. Regulation and enforcement of minimum quality standards makes the CBC "treatment" reasonably comparable in Chile. But results should be interpreted with caution as they may not necessarily apply to other low and middle-income countries, where there may be more variability in regulation and feeding standards.

\section{Limitations}

This study has at least four limitations. First, treatment and control groups were not randomly assigned, which would have allowed us to identify the "true" effect of CBC on BMI. It is possible that children attending CBC were systematically different from children who remained in maternal care. We minimized the risk of systematic bias by restricting our sample to children in maternal care at baseline and using PSM to generate a statistically comparable sample of children in $\mathrm{CBC}$ and maternal care based on observable characteristics at baseline. The results from PSM (supplementary material) confirmed that the predicted probability of attending $C B C$ was comparable for children who attended $C B C$ and those who remained in maternal care for all relevant observable characteristics. Second, ELPI survey lacks measures related to specific dietary intake, a major driver of overweight in children. We tried to address this limitation by including lifestyle variables correlated with dietary intake [98,99], and mother's weight status category as a proxy for household dietary intake. Third, we did not have any measure of $\mathrm{CBC}$ quality. We included a limited amount of $\mathrm{CBC}$ service (attendance time and type of funding), but did not have relevant information such as teacher-pupil ratio, curriculum, class size, and other proxies of CBC quality. Fourth, we could not assess children's physical activity, due to lack of data, but included some behavioral and household characteristics partially addressing this limitation. Our findings may need to be confirmed using a study design with a more robust claim to causality, including a more exhaustive range of factors associated with childhood obesity. Replicating this study in other middle- and low-income countries could provide additional external validity to our findings.

\section{CONCLUSIONS}

Our results suggest $\mathrm{CBC}$ programs, with adequate regulation and enforcement, could help curb the obesity epidemic in early childhood, in addition to known benefits of $C B C[52,53]$. The benefits from these programs could extend for many years, including avoiding health complications later in life. CBC programs, particularly in the context of middle-income countries, may help control BMI increases through improved nutrition, physical activities, and other lifestyle-related measures. If adequate care is provided, there is probably a substitution effect between potentially harmful activities that consume the child's time (eg, watching television) and $\mathrm{CBC}$ attendance. A recent review [100] examined nutritional and physical activity regulations for $\mathrm{CBC}$ in the USA that could help reduce childhood overweight and obesity. The article highlighted some of the challenges of regulation, and the importance of enforcement to secure quality. Here we show $\mathrm{CBC}$ is potentially a good option to curb childhood overweight in middle income countries. 


Acknowledgements: We thank participants at the 2018 Association for Public Policy Analysis \& Management
(APPAM) International Conference in Mexico City, Mexico, at 2018 International Conference of Behavioral
Medicine (ICBM) in Santiago, Chile, and at 2018 Society for Research in Child Development (SRCD; DEVSEC:
Conference on the Use of Secondary and Open Source Data in Developmental Science), Phoenix, EEUU, and
two anonymous reviewers for thoughtful comments and suggestions.
Data availability and ethics: Data from Chilean Early-Childhood Longitudinal Survey 2010 -2012 are pub-
licly available upon request at the Ministerio de Desarrollo Social y Familia, Encuesta Longitudinal de Primera
Infancia (ELPI), http://observatorio.ministeriodesarrollosocial.gob.cl/elpi/elpi_bd.php. The survey was evalu-
ated and approved by the Ethics Committee of the US National Institutes of Health, because of the connection
of Chilean Ministry of Social Development and Universidad de Chile with University of Pennsylvania.
Funding: For research support, the authors thank ANID PIA CIE160007 and the Millennium Science Initia-
tive of the Chilean Ministry of Economy, Development, and Tourism, grant "Millennium Nucleus for the Study
of the Life Course and Vulnerability."
Authorship contributions: KA and MN conceived and designed the study. KA conducted data analyses, in-
terpreted the findings, and wrote a first draft of the manuscript. EU supported data analysis and interpretation
of results. All authors critically reviewed and edited the manuscript.
Competing interests: The authors completed the ICMJE Unified Competing Interest form (available upon re-
quest from the corresponding author), and declare no conflicts of interest.
Additional material
Online Supplementary Document

1 Ng M, Fleming T, Robinson M, Thomson B, Graetz N, Margono C, et al. Global, regional, and national prevalence of overweight and obesity in children and adults during 1980-2013: a systematic analysis for the Global Burden of Disease Study 2013. Lancet. 2014;384:766-81. Medline:24880830 doi:10.1016/S0140-6736(14)60460-8

2 de Onis M, Blössner M, Borghi E. Global prevalence and trends of overweight and obesity among preschool children. Am J Clin Nutr. 2010;92:1257-64. Medline:20861173 doi:10.3945/ajcn.2010.29786

3 Ebbeling CB, Pawlak DB, Ludwig DS. Childhood obesity: public-health crisis, common sense cure. Lancet. 2002;360:47382. Medline:12241736 doi:10.1016/S0140-6736(02)09678-2

4 Swinburn BA, Sacks G, Hall KD, McPherson K, Finegood DT, Moodie ML, et al. The global obesity pandemic: shaped by global drivers and local environments. Lancet. 2011;378:804-14. Medline:21872749 doi:10.1016/S01406736(11)60813-1

5 Popkin BM, Adair LS, Ng SW. Global nutrition transition and the pandemic of obesity in developing countries. Nutr Rev. 2012;70:3-21. Medline:22221213 doi:10.1111/j.1753-4887.2011.00456.x

6 Ogden CL, Carroll MD, Kit BK, Flegal KM. Prevalence of obesity and trends in body mass index among US children and adolescents, 1999-2010. JAMA. 2012;307:483-90. Medline:22253364 doi:10.1001/jama.2012.40

7 Ogden CL, Flegal KM, Carroll MD, Johnson CL. Prevalence and trends in overweight among US children and adolescents, 1999-2000. JAMA. 2002;288:1728-32. Medline:12365956 doi:10.1001/jama.288.14.1728

8 World Health Organization. Report of the commission on ending childhood obesity: Geneva: World Health Organization; 2016.

9 Uauy R, Albala C, Kain J. Obesity trends in Latin America: transiting from under-to overweight. J Nutr. 2001;131:893S9S. Medline:11238781 doi:10.1093/jn/131.3.893S

10 Corvalán C, Garmendia M, Jones-Smith J, Lutter C, Miranda J, Pedraza L, et al. Nutrition status of children in Latin America. Obes Rev. 2017;18:7-18. Medline:28741907 doi:10.1111/obr.12571

11 Obesity prevention in Latin America: now is the time. Lancet Diabetes Endocrinol. 2014;2:263. Medline:24703034 doi:10.1016/S2213-8587(14)70079-8

12 Ministerio de Salud Chile. Diagnóstico del estado nutricional de menores de 6 años, gestantes, nodrizas, y adultos mayores, bajo control en el sistema público de salud. Santiago, Chile: Departamento de Nutrición y Alimentos, División de Políticas Públicas Saludables y Promoción, Subsecretaría de Salud Pública, Ministerio de Salud; 2014.

13 Obesity Collaborators GBD, Afshin A, Forouzanfar MH, Reitsma MB, Sur P, Estep K, et al. Health effects of overweight and obesity in 195 countries over 25 years. N Engl J Med. 2017;377:13-27. Medline:28604169 doi:10.1056/NEJMoa1614362

14 Han JC, Lawlor DA, Kimm SY. Childhood obesity. Lancet. 2010;375:1737-48. Medline:20451244 doi:10.1016/S01406736(10)60171-7

15 Taillie LS, Reyes M, Colchero MA, Popkin B, Corvalán C. An evaluation of Chile’s Law of Food Labeling and Advertising on sugar-sweetened beverage purchases from 2015 to 2017: A before-and-after study. PLoS Med. 2020;17:e1003015. Medline:32045424 doi:10.1371/journal.pmed.1003015

16 Drewnowski A. Obesity and the food environment: dietary energy density and diet costs. Am J Prev Med. 2004;27:15462. Medline:15450626 doi:10.1016/j.amepre.2004.06.011

17 Cutler DM, Glaeser EL, Shapiro JM. Why have Americans become more obese? J Econ Perspect. 2003;17:93-118. doi: $10.1257 / 089533003769204371$ 
18 Finkelstein EA, Ruhm CJ, Kosa KM. Economic causes and consequences of obesity. Annu Rev Public Health. 2005;26:23957. Medline:15760288 doi:10.1146/annurev.publhealth.26.021304.144628

19 Chou S-Y, Grossman M, Saffer H. An economic analysis of adult obesity: results from the Behavioral Risk Factor Surveillance System. J Health Econ. 2004;23:565-87. Medline:15120471 doi:10.1016/j.jhealeco.2003.10.003

20 Philipson TJ, Posner R. The long-run growth in obesity as a function of technological change. Perspect Biol Med. 2003;46(3 Suppl):S87. Medline:14563077 doi:10.1353/pbm.2003.0058

21 Comuzzie AG, Allison DB. The search for human obesity genes. Science. 1998;280:1374-7. Medline:9603720 doi:10.1126/science.280.5368.1374

22 Walley AJ, Asher JE, Froguel P. The genetic contribution to non-syndromic human obesity. Nat Rev Genet. 2009;10:43142. Medline: 19506576 doi:10.1038/nrg2594

23 Xia Q, Grant SF. The genetics of human obesity. Ann N Y Acad Sci. 2013;1281:178. Medline:23360386 doi:10.1111/ nyas. 12020

24 Christakis NA, Fowler JH. The spread of obesity in a large social network over 32 years. N Engl J Med. 2007;357:3709. Medline:17652652 doi:10.1056/NEJMsa066082

25 Knutson KL, Spiegel K, Penev P, Van Cauter E. The metabolic consequences of sleep deprivation. Sleep Med Rev. 2007;11:163-78. Medline:17442599 doi:10.1016/j.smrv.2007.01.002

26 Marshall SJ, Biddle SJ, Gorely T, Cameron N, Murdey I. Relationships between media use, body fatness and physical activity in children and youth: a meta-analysis. Int J Obes Relat Metab Disord. 2004;28:1238-46. Medline:15314635 doi:10.1038/sj.ijo.0802706

27 Jiménez-Pavón D, Kelly J, Reilly JJ. Associations between objectively measured habitual physical activity and adiposity in children and adolescents: Systematic review. Int J Pediatr Obes. 2010;5:3-18. Medline:19562608 doi:10.3109/17477160903067601

28 Popkin BM. The nutrition transition and its health implications in lower-income countries. Public Health Nutr. 1998;1:521. Medline:10555527 doi:10.1079/PHN19980004

29 Brewis AA, Wutich A, Falletta-Cowden A, Rodriguez-Soto I. Body norms and fat stigma in global perspective. Curr Anthropol. 2011;52:269-76. doi:10.1086/659309

30 Vangay P, Johnson AJ, Ward TL, Al-Ghalith GA, Shields-Cutler RR, Hillmann BM, et al. US immigration westernizes the human gut microbiome. Cell. 2018;175:962-72. Medline:30388453 doi:10.1016/j.cell.2018.10.029

31 Flegal KM, Kit BK, Orpana H, Graubard BI. Association of all-cause mortality with overweight and obesity using standard body mass index categories: a systematic review and meta-analysis. JAMA. 2013;309:71-82. Medline:23280227 doi:10.1001/jama.2012.113905

32 Renehan AG, Tyson M, Egger M, Heller RF, Zwahlen M. Body-mass index and incidence of cancer: a systematic review and meta-analysis of prospective observational studies. Lancet. 2008;371:569-78. Medline:18280327 doi:10.1016/S01406736(08)60269-X

33 Must A, Strauss RS. Risks and consequences of childhood and adolescent obesity. Int J Obes Relat Metab Disord. 1999;23 Suppl 2:S2. Medline:10340798 doi:10.1038/sj.ijo.0800852

34 Erickson SJ, Robinson TN, Haydel KF, Killen JD. Are overweight children unhappy?: Body mass index, depressive symptoms, and overweight concerns in elementary school children. Arch Pediatr Adolesc Med. 2000;154:931-5. Medline:10980798 doi:10.1001/archpedi.154.9.931

35 Reilly JJ, Kelly J. Long-term impact of overweight and obesity in childhood and adolescence on morbidity and premature mortality in adulthood: systematic review. Int J Obes (London). 2011;35:891. Medline:20975725 doi:10.1038/ ijo.2010.222

36 Viner RM, Cole TJ. Adult socioeconomic, educational, social, and psychological outcomes of childhood obesity: a national birth cohort study. BMJ. 2005;330:1354. Medline:15901644 doi:10.1136/bmj.38453.422049.E0

37 World Health Organization. Taking Action on Childhood Obesity Report. Geneva: Commission on Ending Childhood Obesity; 2018.

38 French SA, Story M, Perry CL. Self-esteem and obesity in children and adolescents: a literature review. Obes Res. 1995;3:479-90. Medline:8521169 doi:10.1002/j.1550-8528.1995.tb00179.x

39 Monasta L, Batty G, Cattaneo A, Lutje V, Ronfani L, Van Lenthe F, et al. Early-life determinants of overweight and obesity: a review of systematic reviews. Obes Rev. 2010;11:695-708. Medline:20331509 doi:10.1111/j.1467-789X.2010.00735.x

40 Reilly JJ, Kelly L, Montgomery C, Williamson A, Fisher A, McColl JH, et al. Physical activity to prevent obesity in young children: cluster randomised controlled trial. BMJ. 2006;333:1041. Medline:17028105 doi:10.1136/bmj.38979.623773.55

41 Reilly JJ, Armstrong J, Dorosty AR, Emmett PM, Ness A, Rogers I, et al. Early life risk factors for obesity in childhood: cohort study. BMJ. 2005;330:1357. Medline:15908441 doi:10.1136/bmj.38470.670903.E0

42 Gardner DS, Hosking J, Metcalf BS, Jeffery AN, Voss LD, Wilkin TJ. Contribution of early weight gain to childhood overweight and metabolic health: a longitudinal study (EarlyBird 36). Pediatrics. 2009;123:e67-73. Medline:19117849 doi:10.1542/peds.2008-1292

43 Pandita A, Sharma D, Pandita D, Pawar S, Tariq M, Kaul A. Childhood obesity: prevention is better than cure. Diabetes Metab Syndr Obes. 2016;9:83-9. Medline:27042133 doi:10.2147/DMSO.S90783

44 Wang Y, Cai L, Wu Y, Wilson R, Weston C, Fawole O, et al. What childhood obesity prevention programmes work? A systematic review and meta-analysis. Obes Rev. 2015;16:547-65. Medline:25893796 doi:10.1111/obr.12277

45 World Health Organization. Global strategy on diet, physical activity, and health Geneva: WHO; 2004. 
46 Veldhuis L, Vogel I, Renders CM, van Rossem L, Oenema A, HiraSing RA, et al. Behavioral risk factors for overweight in early childhood; the 'Be active, eat right' study. Int J Behav Nutr Phys Act. 2012;9:74. Medline:22704042 doi:10.1186/1479-5868-9-74

47 Brown JE, Broom DH, Nicholson JM, Bittman M. Do working mothers raise couch potato kids? Maternal employment and children's lifestyle behaviours and weight in early childhood. Soc Sci Med. 2010;70:1816-24. Medline:20299142 doi:10.1016/j.socscimed.2010.01.040

48 Popkin BM. Urbanization, lifestyle changes and the nutrition transition. World Dev. 1999;27:1905-16. doi:10.1016/ S0305-750X(99)00094-7

49 Hawkes C, Smith TG, Jewell J, Wardle J, Hammond RA, Friel S, et al. Smart food policies for obesity prevention. Lancet. 2015;385:2410-21. Medline:25703109 doi:10.1016/S0140-6736(14)61745-1

50 Ghazvini A, Mullis RL. Center-based care for young children: Examining predictors of quality. J Genet Psychol. 2002;163:112-25. Medline:11952260 doi:10.1080/00221320209597972

51 Howes C, Phillips DA, Whitebook M. Thresholds of quality: Implications for the social development of children in center-based child care. Child Dev. 1992;63:449-60. Medline:1611946 doi:10.2307/1131491

52 Blau D, Currie J. Pre-school, day care, and after-school care: who's minding the kids? Handbook of the Economics of Education. 2006;2:1163-278.

53 Cascio EU. Maternal labor supply and the introduction of kindergartens into American public schools. J Hum Resour. 2009; 44:140-70.

54 Bernal R, Fernández C. Subsidized childcare and child development in Colombia: effects of Hogares Comunitarios de Bienestar as a function of timing and length of exposure. Soc Sci Med. 2013;97:241-9. Medline:23312302 doi:10.1016/j. socscimed.2012.10.029

55 UNICEF, World Health Organization. Integrating Early Childhood Development (ECD) activities into Nutrition Programmes in Emergencies. Why, What and How. Geneva: UNICEF and WHO; 2012.

56 Sahoo K, Sahoo B, Choudhury A, Sofi N, Kumar R, Bhadoria A. Childhood obesity: causes and consequences. J Family Med Prim Care. 2015;4:187-92. Medline:25949965 doi:10.4103/2249-4863.154628

57 Galván M, Uauy R, Corvalán C, López-Rodríguez G, Kain J. Determinants of cognitive development of low SES children in Chile: a post-transitional country with rising childhood obesity rates. Matern Child Health J. 2013;17:1243-51. Medline:22915146 doi:10.1007/s10995-012-1121-9

58 Kang Sim DE, Cappiello M, Castillo M, Lozoff B, Martinez S, Blanco E, et al. Postnatal Growth patterns in a Chilean Cohort: The role of SES and family environment. Int J Pediatr. 2012;2012:354060. Medline:22666275 doi:10.1155/2012/354060

59 Geoffroy MC, Power C, Touchette E, Dubois L, Boivin M, Séguin JR, et al. Childcare and overweight or obesity over 10 years of follow-up. J Pediatr. 2013;162:753-8.e1. Medline:23140878 doi:10.1016/j.jpeds.2012.09.026

60 Gubbels JS, Kremers S, Stafleu A, Dagnelie P, De Vries N, Van Buuren S, et al. Child-care use and the association with body mass index and overweight in children from 7 months to 2 years of age. Int J Obes (Lond). 2010;34:1480. Medline:20498654 doi:10.1038/ijo.2010.100

61 McGrady ME, Mitchell MJ, Theodore SN, Sersion B, Holtzapple E. Preschool participation and BMI at kindergarten entry: the case for early behavioral intervention. J Obes (Lond). 2010;2010:360407. Medline:20721345 doi:10.1155/2010/360407

62 Lumeng JC, Gannon K, Appugliese D, Cabral HJ, Zuckerman B. Preschool child care and risk of overweight in 6-to 12-year-old children. Int J Obes. 2005;29:60. Medline:15534612 doi:10.1038/sj.ijo.0802848

63 Belfield CR, Kelly IR. Early education and health outcomes of a 2001 US birth cohort. Econ Hum Biol. 2013;11:310-25. Medline:22672886 doi:10.1016/j.ehb.2012.05.001

64 Mandal B, Powell LM. Child care choices, food intake, and children's obesity status in the United States. Econ Hum Biol. 2014;14:50-61. Medline:24958453 doi:10.1016/j.ehb.2014.04.001

65 Lumeng JC, Kaciroti N, Sturza J, Krusky AM, Miller AL, Peterson KE, et al. Changes in body mass index associated with head start participation. Pediatrics. 2015;135:e449-56. Medline:25583912 doi:10.1542/peds.2014-1725

66 Koleilat M, Harrison GG, Whaley S, McGregor S, Jenks E, Afifi A. Preschool enrollment is associated with lower odds of childhood obesity among WIC participants in LA County. Matern Child Health J. 2012;16:706-12. Medline:21431308 doi:10.1007/s10995-011-0774-0

67 Swyden K, Sisson S, Lora K, Castle S, Copeland K. Association of childcare arrangement with overweight and obesity in preschool-aged children: a narrative review of literature. Int J Obes (Lond). 2017;41:1. Medline:2781 1950 doi:10.1038/ ijo.2016.198

68 Tanskanen AO. The association between grandmaternal investment and early years overweight in the UK. Evol Psychol. 2013;11:417-25. Medline:23757603 doi:10.1177/147470491301100212

69 Zahir N, Heyman M, Wojcicki J. No association between childcare and obesity at age 4 in low-income Latino children. Pediatr Obes. 2013;8:e24-8. Medline:23239621 doi:10.1111/j.2047-6310.2012.00125.x

70 Lehto R, Mäki P, Ray C, Laatikainen T, Roos E. Childcare use and overweight in F inland: cross-sectional and retrospective associations among 3-and 5-year-old children. Pediatr Obes. 2016;11:136-43. Medline:25955215 doi:10.1111/ ijpo. 12036

71 McLaren L, Zarrabi M, Dutton D, Auld M, Emery J. Child care: implications for overweight/obesity in Canadian children? Chronic Dis Inj Can. 2012;33:1-11. Medline:23294916

72 Black L, Matvienko-Sikar K, Kearney PM. The association between childcare arrangements and risk of overweight and obesity in childhood: a systematic review. Obes Rev. 2017;18:1170-90. Medline:28677302 doi:10.1111/obr.12575 
73 Alberdi G, McNamara AE, Lindsay KL, Scully HA, Horan MH, Gibney ER, et al. The association between childcare and risk of childhood overweight and obesity in children aged 5 years and under: a systematic review. Eur J Pediatr. 2016;175:1277-94. Medline:27631590 doi:10.1007/s00431-016-2768-9

74 Kimbro RT, Brooks-Gunn J, McLanahan S. Racial and ethnic differentials in overweight and obesity among 3-year-old children. Am J Public Health. 2007;97:298-305. Medline:17194857 doi:10.2105/AJPH.2005.080812

75 Frisvold DE, Giri A. The potential of early childhood education as a successful obesity intervention. In: Brennan VM, Kumanyika SK, Zambrana RE, editors. Obesity Interventions in Underserved Communities: Evidence and Directions. Baltimore, USA: John Hopkins University Press; 2014.</edb>

76 Braithwaite I, Stewart AW, Hancox RJ, Beasley R, Murphy R, Mitchell EA, et al. The worldwide association between television viewing and obesity in children and adolescents: cross sectional study. PLoS One. 2013;8:e74263. Medline:24086327 doi:10.1371/journal.pone.0074263

77 Isong IA, Richmond T, Kawachi I, Avendaño M. Childcare attendance and obesity risk. Pediatrics. 2016;138:e20161539. Medline:27940780 doi:10.1542/peds.2016-1539

78 United Nations. Education for All. Strong foundations: early childhood care and education (vol 2007): United Nations Educational; 2006.

79 Ministerio de Educación de Chile. Estado del arte de la educación parvularia en Chile. Santiago de Chile: Centro de Estudios MINEDUC, División de Planificación y Presupuesto, Ministerio de Educación de Chile; 2014.

80 Bedregal P, Torres A, Carvallo C. Chile crece contigo: El desafío de la protección social a la infancia. Documento de Trabajo Santiago: Programa de las Naciones Unidas para el Desarrollo. 2014.

81 Organisation for Economic Co-operation and Development. Obesity Update 2017. Paris: OECD; 2017.

82 Junta Nacional de Jardines Infantiles. Informe final de evaluación programa jardín infantil JUNJI. Santiago de Chile: Junta Nacional de Jardines Infantiles, Ministerio de Educación; 2015.

83 Mamedova S, Redford J. Early Childhood Program Participation, from the National Household Education Surveys Program of 2012. First Look. Washington DC: US Department of Education; 2015.

84 Waldfogel J. International policies toward parental leave and child care. New York: Columbia University; 2001. Report No.: 1054-8289.

85 Encuesta Longitudinal de Primer Infancia (ELPI). Diseño muestral y factores de expansión segunda ronda encuesta longitudinal de la primera infancia. Santiago: Centro de Microdatos, Departamento de Economía, Universidad de Chile; 2012

86 World Health Organization. UNICEF-WHO-World Bank 2012 Joint child malnutrition estimates. Levels and trends. Geneva: WHO; 2015.

87 World Health Organization. WHO child growth standards: length/height for age, weight-for-age, weight-for-length, weight-for-height and body mass index-for-age, methods and development. Geneva: World Health Organization; 2006.

88 Danielzik S, Czerwinski-Mast M, Langnäse K, Dilba B, Müller M. Parental overweight, socioeconomic status and high birth weight are the major determinants of overweight and obesity in 5-7 y-old children: baseline data of the Kiel Obesity Prevention Study (KOPS). Int J Obes Realt Metab Disord. 2004;28:1494-502. Medline:15326465 doi:10.1038/ sj.ijo.0802756

89 Kanda A, Kamiyama Y, Kawaguchi T. Association of reduction in parental overweight with reduction in children's overweight with a 3-year follow-up. Prev Med. 2004;39:369-72. Medline:15226048 doi:10.1016/j.ypmed.2004.01.033

90 Steffen LM, Dai S, Fulton JE, Labarthe DR. Overweight in children and adolescents associated with TV viewing and parental weight: Project HeartBeat! Am J Prev Med. 2009;37:S50-5. Medline:19524156 doi:10.1016/j.amepre.2009.04.017

91 Geoffroy MC, Côté SM, Giguère CÉ, Dionne G, Zelazo PD, Tremblay RE, et al. Closing the gap in academic readiness and achievement: the role of early childcare. J Child Psychol Psychiatry. 2010;51:1359-67. Medline:20883519 doi:10.1111/j.1469-7610.2010.02316.x

92 Bradley RH, Caldwell BM. The HOME Inventory and family demographics. Dev Psychol. 1984;20:315-20. doi:10.1037/0012-1649.20.2.315

93 Rosenbaum PR, Rubin DB. Constructing a control group using multivariate matched sampling methods that incorporate the propensity score. Am Stat. 1985;39:33-8.

94 Baughcum AE, Powers SW, Johnson SB, Chamberlin LA, Deeks CM, Jain A, et al. Maternal feeding practices and beliefs and their relationships to overweight in early childhood. J Dev Behav Pediatr. 2001;22:391-408. Medline:11773804 doi:10.1097/00004703-200112000-00007

95 Faith MS, Heshka S, Keller KL, Sherry B, Matz PE, Pietrobelli A, et al. Maternal-child feeding patterns and child body weight: findings from a population-based sample. Arch Pediatr Adolesc Med. 2003;157:926-32. Medline:12963600 doi:10.1001/archpedi.157.9.926

96 Story M, Kaphingst KM, French S. The role of child care settings in obesity prevention. New York: Columbia University; 2006. Report No.: 1550-1558 Contract No.: 1.

97 Felisbino-Mendes MS, Villamor E, Velasquez-Melendez G. Association of maternal and child nutritional status in Brazil: a population based cross-sectional study. PLoS One. 2014;9:e87486. Medline:24475297 doi:10.1371/journal. pone.0087486

98 Lioret S, Touvier M, Lafay L, Volatier J-L, Maire B. Dietary and physical activity patterns in French children are related to overweight and socioeconomic status. J Nutr. 2008;138:101-7. Medline:18156411 doi:10.1093/jn/138.1.101

99 Craig LC, McNeill G, Macdiarmid JI, Masson LF, Holmes BA. Dietary patterns of school-age children in Scotland: association with socio-economic indicators, physical activity and obesity. Br J Nutr. 2010;103:319-34. Medline:19835641 doi:10.1017/S0007114509991942

100 Benjamin SE, Cradock A, Walker EM, Slining M, Gillman MW. Obesity prevention in child care: A review of U.S. state regulations. BMC Public Health. 2008;8:188. Medline:18513424 doi:10.1186/1471-2458-8-188 